\title{
PENGARUH PENGGUNAAN STRATEGI KWL (KNOW, WANT, AND LEARN) TERHADAP MINAT MEMBACA DAN KEMAMPUAN EFEKTIF MEMBACA SISWA KELAS IV DI GUGUS VIII KECAMATAN SAWAN
}

\author{
T.Yuliantari' ${ }^{1}$, I. B. Putrayasa ${ }^{2}$, N. Sudiana ${ }^{3}$ \\ Program Studi Pendidikan Dasar, Program Pascasarjana \\ Universitas Pendidikan Ganesha \\ Singaraja, Indonesia \\ e-mail: \{ktrisnay@gmail.com,ib.putryasa@pasca.undiksha.ac.id, \\ nyoman.sudiana@pasca.undiksha.ac.id\}
}

\begin{abstract}
Abstrak
Penelitian ini bertujuan untuk mengetahui perbedaan minat membaca dan kemampuan efektif membaca antara kelompok siswa yang dibelajarkan dengan strategi $\mathrm{KWL}$ (know, want and learn) dan kelompok siswa yang dibelajarkan dengan strategi konvensional pada siswa kelas IV di Gugus VIII Kecamatan Sawan Penelitian ini adalah penelitian eksperimen semu dengan desain post-test only control group design. Populasi dalam penelitian berjumlah 122 siswa sedangkan sampel berjumlah 61 orang siswa. Sampel diperoleh dengan teknik simple random sampling. Data minat membaca siswa dikumpulkan dengan kuesioner, sedangkan data kemampuan efektif membaca siswa dikumpulkan dengan tes pilihan ganda. Analisis data pada penelitian ini menggunakan analisis Manova. Hasil penelitian menunjukkan bahwa 1) terdapat perbedaan yang signifikan minat membaca antara kelompok siswa yang dibelajarkan dengan strategi KWL (know, want and learn) dan kelompok siswa yang dibelajarkan dengan strategi konvensional pada siswa kelas IV di Gugus VIII Kecamatan Sawan, 2) terdapat perbedaan yang signifikan kemampuan efektif membaca antara kelompok siswa yang dibelajarkan dengan strategi KWL (know, want and learn) dan kelompok siswa yang dibelajarkan dengan strategi konvensional pada siswa kelas IV di Gugus VIII Kecamatan Sawan, dan 3) terdapat perbedaan yang signifikan minat membaca dan kemampuan efektif membaca antara kelompok siswa yang dibelajarkan dengan strategi KWL (know, want and learn) dan kelompok siswa yang dibelajarkan dengan strategi konvensional pada siswa kelas IV di Gugus VIII Kecamatan Sawan.
\end{abstract}

Kata kunci: kemampuan efektif, membaca minat membaca, strategi KWL

Abstract

This study aims to determine the differences in reading interest and effective reading ability between groups of students who are taught with KWL (know, want and learn) strategies and groups of students who are taught with conventional strategies in class IV students in Cluster VIII Sawan District. This research is a quasi-experimental study with post-test only control group design. The population in the study amounted to 122 students while the sample amounted to 61 students. The sample is obtained by simple random sampling technique. Data on students 'interest in reading was collected by questionnaire, while data on students' effective reading ability were collected by multiple choice tests. Data analysis in this study using Manova analysis. This shows that 1) there is a significant difference in the interest in reading between the groups of students taught with the KWL (know, want and learn) strategy and the group of students taught with conventional strategies in class IV students in Cluster VIII Sawan District, 2) there are significant differences in the effective reading ability between groups of students which was taught by the KWL strategy and group of students taught with conventional strategies in class IV students in Cluster VIII Sawan District, and 3) there were significant differences in reading interest and effective reading ability between groups of 
ISSN: 2613-9553

students who were taught with KWL (know, want and learn) strategies and groups of students taught with conventional strategy in class IV students in Cluster VIII Sawan District.

Keywords: effective ability, reading interest, KWL strategy

\section{PENDAHULUAN}

Strategi pembelajaran adalah suatu kondisi yang diciptakan oleh guru dengan sengaja agar peserta difasilitasi dalam mencapai tujuan pembelajaran yang ditetapkan. Strategi pembelajaran juga dapat diartikan sebagai pola kegiatan pembelajaran yang dipilih dan digunakan guru secara kontekstual, sesuai dengan karakteristik siswa, kondisi sekolah, lingkungan sekitar serta tujuan khusus pembelajaran yang dirumuskan. Strategi pembelajaran terdiri dari metode dan teknik (prosedur) yang akan menjamin bahwa siswa akan betul-betul mencapai tujuan pembelajaran.

Pembelajaran Bahasa Indonesia merupakan pembelajaran yang kompleks dengan mengutamakan aspek keterampilan berbahasa, yaitu keterampilan menyimak, keterampilan berbicara, keterampilan membaca dan keterampilan menulis (Tarigan, 2008:2). Semua aspek tersebut saling barkaitan satu sama lainnya. Manusia sebagai makhluk sosial tidak dapat terlepas dari keempat keterampilan berbahasa tersebut. Begitu pula dengan siswa yang pada hakikatnya adalah makhluk sosial dalam lingkungannya. Penggunaan terhadap aspek keterampilan berbahasa sangatlah diperlukan agar komunikasi berjalan dengan baik dan lancar. Agar pembelajaran bahasa dapat berjalan. Pada penelitian ini aspek berbahasa yang akan diteliti adalah aspek membaca, karena membaca merupakan salah satu keterampilan berbahasa yang sangat memengaruhi kualitas hidup seseorang. Membaca memiliki peranan sosial yang amat penting dalam kehidupan manusia sepanjang masa karena membaca merupakan suatu alat komunikasi yang sangat diperlukan dalam suatu masyarakat berbudaya.

Membaca merupakan suatu aktivitas yang sangat jamak dilakukan bagi siapa pun, di mana pun bahkan kapan pun. Seseorang cenderung lebih banyak membaca daripada menonton atau pun mendengar tatkala seseorang mencari informasi yang dibutuhkan. Di samping itu pula, menurut para ahli, aktivitas membaca sebenarnya merupakan satu-satunya cara yang cepat dalam menyerap dan memahami data atau informasi, karena ketika membaca, otak seseorang sebenarnya ikut aktif menangkap informasi tersebut (Nuriadi, 2008:40).

Banyak pandangan mengenai
pengertian membaca.
merupakan suatu proses yang dilakukan dan digunakan seseorang untuk memeroleh pesan yang terdapat dalam bahasa tulis. Melalui kegiatan membaca, seseorang akan dapat menggali dan mencari berbagai macam ilmu pengetahuan yang tersimpan dalam bukubuku dan media tulis lainnya (Sudiana, 2007:2).

Membaca merupakan aktivitas yang kompleks dengan mengerahkan sejumlah besar tindakan yang terpisahpisah, meliputi orang harus menggunakan pengertian dan khayalan, mengamati dan mengingat-ingat (Soedarso, 2004:4). Berdasarkan beberapa uraian pernyataan yang telah disampaikan pada bagian terdahulu, dapat disimpulkan bahwa membaca merupakan aktivitas kompleks yang dilakukan dan digunakan seseorang untuk memeroleh pesan yang hendak disampaikan oleh penulis melalui media kata-kata atau bahasa tulis. Rosenblatt (dalam Marhaeni, 1998: 207) berpendapat bahwa membaca merupakan proses 


$\begin{array}{lrr}\text { transaksional. } & \text { Proses } & \text { membaca } \\ \text { berdasarkan pendapat ini } & \text { meliputi } \\ \text { langkah-langkah selama } & \text { pembaca } \\ \text { mengkonstruks makna } & \text { melalui } \\ \text { interaksinya dengan teks bacaan. Makna } \\ \text { tersebut dihasilkan melalui proses } \\ \text { transaksional. Dengan demikian, makna } \\ \text { teks bacaan itu tidak semata-mata } \\ \text { terdapat dalam teks bacaan atau } \\ \text { pembaca saja. }\end{array}$

Kembali ke era yang penuh dengan informasi yang terus berkembang, membaca tidak lagi hanya sekedar sebagai kesenangan, tetapi memang harus dilatih untuk menjadi sebagai kebutuhan. Artinya, setiap orang wajib mengejar semua informasi. la harus memiliki keterampilan mengumpulkan data dengan cepat sekaligus benar. Untuk mencapai hal tersebut, kemampuan efektif membaca menjadi hal utama yang perlu diperhatikan. Dengan memahami kemampuan efektif membaca, kita dapat melihat diri sendiri termasuk kategori pembaca yang bagaimana sehingga dapat terus membekali diri dalam pencapaian target seandainya yang terlihat tidak sesuai dengan harapan.

\begin{tabular}{lrr}
\multicolumn{1}{c}{ Abidin, } & $(2010: 134)$ & menuliskan \\
macam-macam & strategi & membaca \\
pemahaman. & Strategi-strategi & tersebut \\
adalah: & &
\end{tabular}

1) DRA (Direct Reading Activity); 2) DRTA (Direct Reading Thingking Activity); 3) ECOLA (Extending Concept Through Language Activities); 4) GIST (Generating Interaction between Schemata and Text); 5) ReQuest; 6) KWL (Know-Want to knowLearned); 7) SR (Shared Reading); 8) GR (Guide Reading); 9) CIRC (Cooperative Integrated Reading and Composition); 10) REAP (Read, Encode, Annotate, Ponder); 11) PORPE (Predict, Organize, Rehearse, Practice, Evaluate); 12) OK4R (Overview, Key, Read, Recall, Reflect, Review); 13) PQ4R (Preview, Question, Read, Reflect, Recite, Preview); 14) Membaca Kritis; dan 15) CALLA (Cognitive Academic Language Learning Approach).
Dari sejumlah strategi tersebut, KWL merupakan strategi yang melihat secara tahap demi tahap akan kemampuan pemahaman terhadap sebuah bacaan yang dilakukan oleh siswa. Mulai dari tahapan prabaca, siswa diharapkan mampu mengungkapkan apa yang telah diketahui atau informasi apa yang telah dimiliki. terhadap topik yang sedang dibahas, saat membaca; siswa diminta untuk bertanya apa yang ingin diketahui mengenai topik yang sedang dibahas, dan setelah membaca; informasi apa yang telah didapat tentang topik yang sedang dibahas. Hal ini dianggap dapat lebih memudahkan siswa dalam memahami bacaan yang dibaca serta dapat meningkatkan minat membaca. Meskipun demikian, pembenaran tersebut belumlah bisa dipastikan 100\% kebenarannya, hal ini dikarenakan oleh banyak sekolah yang menerapkan strategistrategi dalam meningkatkan keterampilan membaca sampai kepada pemahaman terhadap bacaan, namun hasil yang diinginkan belumlah seperti apa yang diharapkan yaitu anak-anak mampu memahami bacaan yang dibaca dengan cepat dan tepat. Seperti yang telah disebutkan, salah satu yang sangat berdampak ketika anak memiliki kemampuan membaca permulaan yang baik yang kemudian berlanjut pada membaca pemahaman adalah semakin tertariknya anak dalam membaca. Minat membaca di sini adalah anak semakin terdorong untuk terus meningkatkan intensitas membacanya. Oleh karena meningkatnya intensitas membaca anak, tanpa disadari prestasi membaca anak semakin meningkat. Seseorang akan dituntut untuk membedakan informasi yang diperlukan atau tidak. Informasi itu kemudian disimpan dalam otak. Memiliki KEM yang tinggi di abad informasi akan menempatkan kita pada posisi kehidupan yang layak. Dengan adanya rasa tanggung jawab bersama dan kesadaran diri, kita berharap dapat mewujudkan 
masyarakat yang memiliki minat membaca yang tinggi.

Berdasarkan latar belakang tersebut, penulis tertarik untuk meneliti tentang keefektifan penggunaan strategi $\mathrm{KWL}$ dalam meningkatkan minat membca dan kemampuan efektif membaca (KEM). Pada penelitian ini ingin dilihat bahwa apakah strategi KWL tersebut mampu meningkatkan KEM siswa serta pengaruhnya terhadap minat membaca siswa setelah mengetahui kemampuan efektif membacanya.

\section{METODE PENELITIAN}

Penelitian ini bertujuan untuk mengetahui kemampuan efektif membaca dan minat membaca. Penelitian ini menggunakan metode penelitian eksperimen Ada berbagai variasi dari penelitian eksperimen, dan pada penelitian ini menggunakan jenis penelitian eksperimen semu atau eksperimen kuasi, hal ini dilihat dari subjek eksperimen yang tidak dirandomisasi untuk menentukan sampel guna ditempatkan dalam kelompok eksperimen dan kelompok kontrol.

Desain rancangan eksperimen pada penelitian ini menggunakan dua kelompok, yaitu kelompok eksperimen (experiment group) dan kelompok kontrol (control group). Pelaksanaan penelitian diklasifikasi menjadi tiga bagian, yaitu: materi pembelajaran, strategi pembelajaran dan waktu pelaksanaan. Strategi pembelajaran pada penelitian ini adalah strategi KWL (know want to know learned) sebagai kelompok eksperimen dan strategi pembelajaraan konvensional sebagai kelompok kontrol. Materi pembelajaran yang dipilih terlebih dahulu dikaji karakteristiknya guna dipadukan pada pembelajaran strategi KWL (know want to know learned) yang kemudian dijabarkan dalam rencana pelaksanaan pembelajaran (RPP).

Populasi dari penelitian ini adalah seluruh siswa kelas IV SD di Gugus VIII
Kecamatan Sawan tahun pelajaran 2018/2019. Di Gugus VIII terdapat 6 SD yaitu SD Negeri 1 Sudaji, SD Negeri 2 Sudaji, SD Negeri 3 Sudaji,SD Negeri 4 Sudaji, SD Negeri 6 Sudaji. Jumlah siswa kelas IV SD di Gugus VIII Kecamatan Sawan tahun pelajaran 2018/2019 sebanyak 122 orang siswa.

Sampel penelitian pada penelitian ini diambil secara random sampling. Sebelum dilakukan random sampling, terlebih dahulu dilakukan uji kesetaraan. Berdasarkan hasil analisis uji kesetaraan dengan menggunakan analisis Anava Satu Jalur didapatkan nilai $F$ hitung sebesar 0,792 dengan signifikansi sebesar 0,557. Hasil tersebut mengindikasikan signifikansi lebih besar dari $0,05 \quad(p>0,05)$, sehingga dapat disimpulkan seluruh sampel pada penelitian ini memiliki kemampuan yang setara.

Setelah diketahui seluruh sampel memiliki kemampuan yang setara, selanjutnya dilanjutkan dengan mengundi keenam kelas untuk menentukan sampel yang digunakan penelitian. Berdasarkan pengundian yang telah dilakukan, didapatkan hasil SD Negeri 2 Sudaji sebagai kelas eksperimen dan SD Negeri 3 Sudaji sebagai kelas kontrol.

Pada penelitian ini yang menjadi variabel bebas adalah strategi pembelajaran, yang terdiri dari strategi KWL (know want to know learned) yang dikenakan pada kelas eksperimen dan strategi konvensional yang dikenakan pada kelompok kontrol. Sedangkan variabel terikat pada penelitian ini adalah minat membaca dan kemampuan efektif membaca.

Data minat membaca siswa pada penelitian ini dikumpulkan dengan kuesioner, sedangkan data kemampuan efektif membaca siswa dikumpulkan dengan tes pilihan ganda.

Data yang sudah dikumpulkan ditabulasi rerata dan simpangan baku menyangkut data minat membaca dan kemampuan efektif. Analisis statistik yang 
ISSN: 2613-9553

digunakan untuk menguji hipotesis adalah dengan menggunakan MANOVA.

\section{HASIL PENELITIAN DAN PEMBAHASAN}

Data yang didapatkan pada penelitian ini terlebih dahulu dilakukan analisis deskriptif data. Analisis deskriptif dilakukan untuk mencari mean, median, modus, serta standar deviasi dari tiap-tiap kelompok data. Hasil perhitungan tersebut dapat dilihat pada Tabel 1.

Tabel 1 Rekapitulasi Hasil Perhitungan Skor Minat Membaca dan Kemampuan Efektif Membaca Siswa

\begin{tabular}{|c|c|c|c|c|}
\hline Statistik Variabel & $\mathrm{A}_{1} \mathrm{Y}_{1}$ & $\mathrm{~A}_{1} \mathrm{Y}_{2}$ & $\mathrm{~A}_{2} \mathrm{Y}_{1}$ & $\mathrm{~A}_{2} \mathrm{Y}_{2}$ \\
\hline $\mathrm{N}$ & 29 & 29 & 32 & 32 \\
\hline Mean & 120,55 & 245,72 & 106,38 & 213,41 \\
\hline Median & 121 & 246 & 107 & 213,5 \\
\hline Modus & 128 & 243 & 107 & 218 \\
\hline Standar Deviasi & 6,58 & 7,76 & 7,35 & 5,60 \\
\hline Varians & 43,33 & 60,21 & 53,98 & 31,41 \\
\hline Rentangan & 21 & 31 & 25 & 21 \\
\hline Skor Minimum & 109 & 231 & 93 & 203 \\
\hline Skor Maksimum & 130 & 262 & 118 & 224 \\
\hline Jumlah & 3496 & 7126 & 3404 & 6829 \\
\hline
\end{tabular}

Keterangan:

$A_{1} Y_{1}=$ Minat membaca siswa yang mengikuti pembelajaran strategi $\mathrm{KWL}$

$A_{1} Y_{2}=$ Kemampuan efektif membaca siswa yang mengikuti pembelajaran dengan strategi KWL

$\mathrm{A}_{2} \mathrm{Y}_{1}=$ Minat Membaca siswa yang mengikuti pembelajaran dengan strategi konvensional.

$\mathrm{A}_{2} \mathrm{Y}_{2}=$ Kemampuan efektif membaca siswa yang mengikuti pembelajaran dengan strategi konvensional.

Setelah dilakukan analisis terhadap data, diperoleh skor minimum = 109 skor maksimum $=130$, rentangan $=$ 21 , rata-rata $=120,55$, standar deviasi $=$ 6,58 , modus $=128$, dan median 121 . Rata-rata skor Minat Membaca siswa yang mengikuti pembelajaran dengan pembelajaran model strategi $\mathrm{KWL}$ adalah 120,55 berada pada interval $108 \leq X$. Berdasarkan tabel katagori di atas diketahui bahwa data minat membaca siswa yang mengikuti pembelajaran strategi KWL termasuk pada katagori "sangat tinggi".

Setelah dilakukan analisis terhadap data kemampuan efektif membaca, diperoleh skor minimum $=231$ skor maksimum $=262$, rentangan $=31$, rata-rata $=245,72$, standar deviasi $=7,76$, modus $=243$, dan median 246. Rata-rata skor kemampuan efektif membaca yang mengikuti pembelajaran dengan pembelajaran strategi KWL adalah 245,72 berada pada interval $225-282$. Berdasarkan tabel katagori di atas 
diketahui bahwa data kemampuan efektif membaca yang mengikuti pembelajaran strategi KWL termasuk pada katagori "cepat".

Setelah dilakukan analisis terhadap data, diperoleh skor minimum = 93 , skor maksimum $=118$, rentangan $=25$, rata-rata $=106,38$, standar deviasi $=7,35$ modus $=107$, dan median 107. Rata-rata skor Minat Membaca siswa yang mengikuti pembelajaran dengan strategi konvensional adalah 106,38 berada pada interval $90 \leq X<108$. Berdasarkan tabel katagori di atas diketahui bahwa data minat membaca siswa yang mengikuti pembelajaran dengan strategi konvensional termasuk pada katagori "tinggi".

Setelah dilakukan analisis terhadap data kemampuan efektif membaca, diperoleh skor minimum $=203$ skor maksimum $=224$, rentangan $=21$, rata-rata $=213,41$, standar deviasi $=5,60$, modus $=218$ dan median 213,5. Rata-rata skor Kemampuan Efektif Membaca yang mengikuti pembelajaran dengan strategi konvensional adalah 213,41 berada pada interval 161 - 224. Berdasarkan tabel katagori di atas diketahui bahwa data kemampuan efektif membaca yang mengikuti pembelajaran dengan strategi konvensional termasuk pada katagori "sedang".

Berdasarkan pengujian hipotesis yang telah dilakukan, didapatkan hasil sebagai berikut.

1) Terdapat perbedaan yang signifikan minat membaca antara kelompok siswa yang dibelajarkan dengan strategi KWL (Know Want To Know Learned) dan kelompok siswa yang dibelajarkan dengan strategi konvensional pada siswa kelas IV di Gugus VIII Kecamatan Sawan
Pengujian hipotesis pertama mendapatkan nilai $F$ sebesar 62,492 dengan signifikansi 0,000. Apabila ditetapkan taraf signifikansi $\alpha=0,05$, maka nilai signifikansi jauh lebih kecil daripada $\alpha$ sehingga $F$ signifikan. Hal ini berarti bahwa $\mathrm{H}_{0}$ ditolak dan menerima $\mathrm{H}_{1}$ yang menyatakan bahwa terdapat perbedaan yang signifikan minat membaca antara kelompok siswa yang mengikuti pembelajaran dengan strategi KWL dengan kelompok siswa yang mengikuti pembelajaran dengan strategi konvensional pada siswa kelas IV SD Gugus VIII Sawan. Jadi, berdasarkan hasil uji hipotesis 1 dapat disimpulkan bahwa terdapat perbedaan yang signifikan signifikan minat membaca antara kelompok siswa yang mengikuti pembelajaran dengan strategi KWL dengan kelompok siswa yang mengikuti pembelajaran dengan strategi konvensional pada siswa kelas IV SD Gugus VIII Sawan.

Hasil penelitian ini sejalan dengan hasil penelitian yang dilakukan oleh Asriani Pada Tahun 2017 dengan penelitiannya yang berjudul "Penerapan Strategi Pembelajaran KWL (Know-WantLearned) Untuk Meningkatkan Kemampan Membaca Pemahaman Pada Siswa Tunarungu Kelas VII di SLB YPP Bajeng Raya Kabupaten Gowa". Hasil penelitian ini menunjukkan bahwa kemampuan membaca pemahaman siswa meningkat ketika menggunakan stratei KWL dibandingkan menggunakan strategi konvensional.

Rahim (2007:28) mengemukakan bahwa minat baca ialah keinginan yang kuat disertai usaha-usaha seseorang untuk membaca. Seseorang yang mempunyai minat membaca yang kuat akan diwujudkannya dalam kesediaannya untuk mendapat bahan bacaan dan kemudian membacanya atas kesadaran sendiri atau dorongan dari luar. Minat membaca juga merupakan perasaan senang seseorang terhadap bacaan 
karena adanya pemikiran bahwa dengan membaca itu dapat diperoleh kemanfaatan bagi dirinya.

Untuk meningkatkan minat baca siswa, strategi yang dapat dilakukan adalah dengan menerapkan strategi $\mathrm{KWL}$ dalam proses pembelajaran. $K-W-L$ adalah strategi membaca instruksional yang digunakan untuk memandu siswa melalui teks. Siswa mulai dengan melakukan brainstorming segala sesuatu yang mereka tahu tentang suatu topik. Informasi ini dicatat dalam kolom $\mathrm{K}$ dari grafik K-W-L. Siswa kemudian menghasilkan daftar pertanyaan tentang apa yang mereka Ingin Tahu tentang topik.

Dengan menerapkan strategi KWL ini, siswa diajak untuk dapat menggali pengetahuan awal (know), menggali sebanyak-banyaknya pertanyaan (want) serta mempelajari banyak hal (learn). Hal ini akan aktif membaca siswa. Dengan penerapan strategi ini, siswa dapat melatih kemampuan efektif membacanya. Dengan terlatihnya siswa membaca maka otomatis membuat siswa terbiasa membaca. Dari terbiasanya siswa membaca, otomatis minat baca siswa menjadi muncul dan terlatih. Berdasarkan pemaparan tersebut dapat disimpulkan bahwa penerapan strategi KWL secara efektif dapat meningkatkan minat baca siswa.

2) Terdapat perbedaan yang signifikan kemampuan efektif membaca antara kelompok siswa yang dibelajarkan dengan strategi KWL (Know Want To Know Learned) dan kelompok siswa yang dibelajarkan dengan strategi konvensional pada siswa kelas IV di Gugus VIII Kecamatan Sawan

$$
\text { Pengujian hipotesis kedua }
$$
mendapatkan nilai $F$ sebesar 352,496 dengan signifikansi 0,000. Apabila ditetapkan taraf signifikansi $\alpha=0,05$, maka nilai signifikansi lebih kecil daripada $\alpha$ sehingga $F$ signifikan. Hal ini berarti bahwa $\mathrm{H}_{0}$ ditolak dan menerima $\mathrm{H}_{1}$ yang menyatakan bahwa terdapat perbedaan yang signifikan kemampuan efektif membaca antara kelompok siswa yang mengikuti pembelajaran dengan strategi $\mathrm{KWL}$ dengan kelompok siswa yang mengikuti pembelajaran dengan strategi konvensional pada siswa kelas IV SD Gugus VIII Sawan. Jadi, berdasarkan hasil uji hipotesis 2 dapat disimpulkan bahwa terdapat perbedaan yang signifikan kemampuan efektif membaca antara kelompok siswa yang mengikuti pembelajaran dengan strategi KWL dengan kelompok siswa yang mengikuti pembelajaran dengan strategi konvensional pada siswa kelas IV SD Gugus VIII Sawan.

Hasil penelitian ini sejalan dengan hasil penelitian yang dilakukan oleh Harsono pada tahun 2016 dengan penelitiannya yang berjudul "Pengaruh Strategi Know Want To Know Learn (KWL) Terhadap Kemampuan Membaca Intensif Siswa SMP Negeri di Temanggung". Hasil penelitian ini menunjukkan bahwa proses pembelajaran membaca intensif lebih menarik dan mudah dipahami, ketika menerapkan strategi KWL, jika dibandingkan dengan pembelajaran konvensional. Hal ini karena dalam penerapan strategi $\mathrm{KWL}$ pembelajaran, membaca intensif siswa menjadi lebih meningkat.

Kemampuan membaca seseorang salah satunya ditentukan oleh ketepatan seorang pembaca menentukan strategi baca yang akan ia gunakan selama ia membaca. Begitu juga dengan pembaca yang fleksibel di mana mampu secara tepat menentukan kecepatan membaca yang ia gunakan untuk mencapai derajat pemahaman yang ia harapkan. Melihat konsep ini, jelaslah bahwa salah satu hal penting yang dapat kita gunakan untuk meningkatkan kemampuan membaca adalah secara tepat menentukan strategi baca. 
Penerapan strategi pembelajaran konvensional, keterampilan membaca hanya dilakukan dengan mengajak siswa membaca, kemudian menjawab soal-soal yang terkait dengan bacaan yang disediakan, kemudian memeriksa dengan kunci jawaban yang telah disediakan oleh guru. Hal ini sesungguhnya dapat menimbulkan dampak negatif bagi siswa, karena tanpa disadari hal ini akan membuat siswa malas berpikir untuk mendapatkan jawaban yang benar karena guru sudah akan memberikan jawaban. Di samping itu pembelajaran akan menjadi pasif karena interaksi yang terjadi hanya interaksi dua arah, antara siswa dan guru, dengan mengabaikan interaksi siswa dengan siswa.

Sementara strategi KWL merupakan salah satu alternatif guru dalam merencanakan dan melaksanakan proses pembelajaran. Strategi ini pada dasarnya adalah sebuah upaya untuk memperbaiki dan membangun kembali iklim sosial pada diri peserta didik melalui proses pembelajaran. Dalam pelaksanaan pembelajaran dengan strategi ini, guru mengajak siswa untuk menggali pengetahua awalnya dan belajar bersama untuk mendapat hal yang ingin dicapai dalam proses pembelajaran serta menemukan jawaban yang benar dari masalah yang ada, dan guru merangkum pendapat-pendapat siswa untuk menghasilkan jawaban yang paling tepat. Bukan semata-semata hanya menunggu kunci jawaban yang benar dari guru. Hal ini membuat siswa aktif membaca. Dengan penerapan strategi ini, dapat melatih kemampuan efektif membacanya.

Berdasarkan pemaparan di atas dapat disimpulkan bahwa penerapan strategi KWL secara efektif dapat meningkatkan Kemampuan Efektif Membaca siswa.
3) Terdapat perbedaan yang signifikan minat membaca dan kemampuan efektif membaca antara kelompok siswa yang dibelajarkan dengan strategi KWL (Know Want To Know Learned) dan kelompok siswa yang dibelajarkan dengan strategi konvensional pada siswa kelas IV di Gugus VIII Kecamatan Sawan

Pengujian hipotesis ketiga mendapatkan nilai $\mathrm{F}$ untuk Pillai's Trace, Wilks' Lambda, Hotelling's Trace, dan Roy's Largest Root sebesar 206,482 dengan nilai signifikansi 0,000 . Apabila ditetapkan taraf signifikansi $\alpha=0,05$, maka nilai signifikansi jauh lebih kecil dari pada a sehingga $F$ signifikan. Hal ini berarti bahwa $\mathrm{H}_{0}$ ditolak dan menerima $\mathrm{H}_{1}$ yang menyatakan bahwa terdapat perbedaan yang signifikan minat membaca dan kemampuan efektif membaca secara simultan antara kelompok siswa yang mengikuti pembelajaran dengan strategi KWL dengan kelompok siswa yang mengikuti pembelajaran dengan strategi konvensional pada siswa kelas IV SD Gugus VIII Sawan. Jadi, berdasarkan hasil uji hipotesis 3 dapat disimpulkan bahwa secara signifikan terdapat perbedaan yang signifikan minat membaca dan kemampuan efektif membaca secara simultan antara kelompok siswa yang mengikuti pembelajaran dengan strategi $\mathrm{KWL}$ dengan kelompok siswa yang mengikuti pembelajaran dengan strategi konvensional pada siswa kelas IV SD Gugus VIII Sawan.

Implementasi strategi KWL (know want to know learned) dalam pembelajaran di kelas dibagi menjadi tiga langkah pokok sesuai dengan karateristiknya yang meliputi langkah know, want and learned. Ketiga langkah tersebut adalah sebagai berikut.

Langkah know (prabaca), guru memandu siswa untuk menggali pengetahuan mereka terhadap apa yang diketahuinya sebelum membaca. Untuk 
membangkitkan pengetahuan siswa terhadap bacaan yang akan dibacanya disajikan sebuah gambar dan judul bacaan. Dengan demikian, gambar dan judul bacaan merupakan media utama dalam kegiatan ini. Semua informasi yang diketahui siswa berhubungan dengan gambar dan topik bacaan yang ditampilkan guru selanjutnya dituliskan pada kolom know (apa yang diketahui) yang sudah disiapakan.

Langkah want (saat baca), inti kegiatan pada tahap ini adalah siswa menyusun pertanyaan-pertanyaan tentang apa yang ingin dipelajarinya dan membaca dalam hati untuk menemukan informasi yang ingin dipelajari. Pertanyaan yang dibuat siswa disesuaikan dengan hasil prediksinya pada tahap know. Kegiatan selanjutnya, guru membagikan teks bacaan kepada semua siswa, kemudian siswa membaca dalam hati teks bacaan tersebut untuk menjawab pertanyaan-pertanyaan yang telah dibuat.

Langkah learned (pascabaca), setelah membaca siswa harus menuliskan informasi yang diingatnya dari bacaan. Inti kegiatan pada tahap ini, yaitu siswa menuliskan informasi yang diperolehnya dari bacaan, memeriksa kembali pertanyaan-pertanyaan yang telah dibuatnya dan membandingkan hasil prediksi awal dengan informasi yang diperoleh. Guru perlu memberi semangat dan motivasi kepada siswa agar tidak merasa bersalah karena hasil prediksinya berbeda dengan hasil yang diperoleh. Semakin ada kesamaan antara prediksi awal dengan hasil yang diperoleh menandakan pemahaman siswa semakin baik.

Penerapan strategi pembelajaran KWL diharapkan mampu mengatasi kejenuhan dan kebosanan siswa dengan menjadikan mereka sebagai fokus pembelajaran. Hal ini akan menjadi motivasi bagi siswa dalam melaksanakan kegiatan pembelajaran. Dengan diterapkan strategi KWL ini mampu meningkatkan kemampuan efektif membaca dan minat membaca siswa.

\section{PENUTUP}

Berdasarkan penelitian yang telah dilakukan, dapat disimpulkan beberapa hal sebagai berikut.

1. Terdapat perbedaan yang signifikan minat membaca antara kelompok siswa yang dibelajarkan dengan strategi KWL (Know Want To Know Learned) dan kelompok siswa yang dibelajarkan dengan strategi konvensional pada siswa kelas IV di Gugus VIII Kecamatan Sawan.

2. Terdapat perbedaan yang signifikan kemampuan efektif membaca antara kelompok siswa yang dibelajarkan dengan strategi KWL (Know Want To Know Learned) dan kelompok siswa yang dibelajarkan dengan strategi konvensional pada siswa kelas IV di Gugus VIII Kecamatan Sawan.

3. Terdapat perbedaan yang signifikan minat membaca dan kemampuan efektif membaca antara kelompok siswa yang dibelajarkan dengan strategi KWL (Know Want To Know Learned) dan kelompok siswa yang dibelajarkan dengan strategi konvensional pada siswa kelas IV di Gugus VIII Kecamatan Sawan.

Dari simpulan yang telah dipaparkan, dapat diberikan beberapa saran sebagai berikut.

1. Siswa disarankan menggunakan strategi KWL untuk meningkatkan minat dan kemampuan membacanya. Agar minat membaca dan kemampuan efektif membaca lebih meningkat.

2. Guru disarankan untuk menggunakan strategi KWL pada pembelajaran membaca untuk meningkatkan minat 
membaca dan kemampuan efektif membaca siswa.

3. Sekolah disarankan untuk menyusun kebijakan KWL dalam rangka meningkatkan minat membaca dan kemampuan efektif membaca siswa.

4. Peneliti lain disarankan untuk mengembangkan penelitian tentang strategi KWL ini, sehingga permasalahan dalam dunia pendidikan dapat diminimalkan.
Nuriadi. 2008. Pembaca Teknik Jitu menjadi Terampil. Yogyakarta: Pustaka Pelajar.

Rahim, Farida. 2007 . Pengajaran Membaca di Sekolah Dasar (Edisi Kedua), Jakarta: Bumi Aksara.

Soedarso, 2004. Speed Reading Sistem Membaca Cepat dan Efektif. Jakarta: PT Gramedia Pustaka Utama.

Sudiana, I Nyoman. 2007. Membaca. Malang: Universitas Negeri Malang (UM Press).

Tarigan, Henry Guntur. 2008. Pengajaran Pragmatik. Bandung: Angkasa.

\section{DAFTAR RUJUKAN}

Abidin, Yunus. 2010. Strategi Membaca Teori dan Pembelajaranya. Bandung: Risqi Press.

Asriani, Ahmad. 2017. Penerapan Strategi Pembelajaran KWL (KnowWant-Learned) Untuk Meningkatkan Kemampuan Membaca Pemahaman pada Siswa Tunarungu Kelas VII Di SLB YPP Bajeng Raya Kabupaten Gowa Tahun 2017. Tersedia pada http://eprints.unm.ac.id/id/eprint /8442.(Diakses pada 3 Desember 2018).

Harsono, A.S.R. 2012. Pengaruh Strategi Know Want To Know Learned (KWL) Terhadap Kemampuan Membaca Intensif Siswa SMP Negeri di Temanggung. Basastra Jurnal Peneltian Bahasa, Sastra Indonesia dan Pengajarannya. Vol 1 (2012). (Diakses pada 15 Juni 2018).

Marhaeni, A.A.I.N. 1998. Rosenblatt's Transactional Theory and Its Implementation In The Teaching Of Integrated Reading. Jurnal IImu Pendidikan. Vol 5, No 4. 